\title{
Reproductive cycles of Mytilus edulis L. on the west and east coasts of Iceland
}

\author{
Gudrun G. Thorarinsdóttir \& Karl Gunnarsson
}

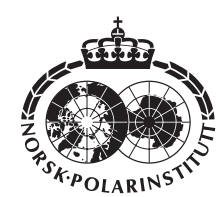

Studies evaluating the reproductive pattern of Mytilus edulis L. were conducted in western and eastern Iceland at two sites at about the same latitude but with different temperature regimes. Mussels were sampled once or sometimes twice a month during two years in Breidifjördur, western Iceland and one year at Mjoifjördur, eastern Iceland. Gonad development was monitored by microscopic observation of thin sections of the gonads. The initiation of gonad development was observed in January in Breidifjördur while in Mjoifjördur some of the animals started developing gonads in October, a month before spawning was over in the population. Spawning started in late June or July, peaked in August and continued until November at both sites. Nutrient reserve stores seemed to be limited and used for initiation of gonad development in winter but were not sufficient for maturation of the gonads. The main growth of the gonads occured in spring in conjunction with phytoplankton blooming and renewal of food resources.

G. G. Thorarinsdóttir \& K. Gunnarsson, Marine Research Institute, Skúlagata 4, IS-101 Reykjavík, Iceland. gutho@hafro.is.

Considerable effort has been devoted to research on different aspects of the reproduction of the marine mussel Mytilus edulis L. in different parts of the world (Seed \& Suchanek 1992). Because of the commercial importance of M. edulis in the North Atlantic, comprehensive studies have been undertaken and the literature relating to reproduction is particularly extensive for the area (Seed 1969, 1976; Seed \& Brown 1977; Brousseau 1983; Sprung 1983; Barkati 1990; Snodden \& Roberts 1997). However, in Iceland investigations of the reproduction of this species are sparse (Thorarinsdóttir 1996).

M. edulis is a sedentary organism and subjected to a wide range of environmental conditions. The interaction between reproductive processes and environmental changes may assume great importance for the well-being of the population. Great variations have been observed in the reproduction pattern of $M$. edulis. These variations have been linked to different environmen- tal factors such as temperature and food availability, thought to effect reproduction of mussels (Giese 1959; Seed 1976; Kautsky 1982; Newell et al. 1982; Starr et al. 1990). However, no conclusive evidence of a direct effect of environmental factors on the initiation of different phases in the development and maturation of gonads has been presented except in the case of the onset of spawning in already ripe individuals (see e.g. Starr et al. 1990). In the North Atlantic M. edulis is subjected to environmental conditions characterized by extremely low water temperatures for several months of the year.

In an attempt to more clearly define the gametogenic cycle and spawning of $M$. edulis in Iceland and to make comparisons with other populations in the North Atlantic the results of a two year study in Breidifjördur, western Iceland, and a one year study in Mjoifjördur, eastern Iceland (Fig. 1), are presented in this paper. Furthermore, the gametogenic cycle and spawning time are 


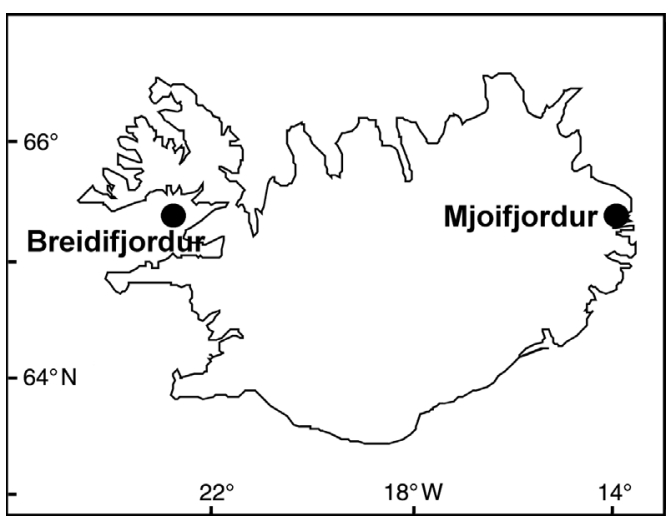

Fig. 1. The study sites for Mytilus edulis in western and eastern Iceland.

considered in relation to temperature and food availability as reflected in concentrations of chlorophyll-a (Chl-a).

\section{Material and methods}

Throughout the study period the sea temperature was monitored at $2 \mathrm{~m}$ depth every two hours with a continuous temperature recorder $\left(\right.$ Starmon $^{\circledR}$, Star-Oddi, Reykjavík) close to both sampling sites (Fig. 1). At the same sites 1 liter seawater samples were taken at $2 \mathrm{~m}$ depth twice a month in the beginning and the end of the year and once a week from the middle of March to the end of September for analysis of Chl-a and $300 \mathrm{ml}$ to measure salinity. The chlorophyll samples were filtered through GF/C filters, which were frozen for later analysis. In the laboratory the chlorophyll was extracted from the filters with $90 \%$ acetone and the extract measured with a spectrophotometer (Jeffrey \& Humphrey 1975). The salinity was measured with a conductivity meter against standard salinity solution (DHI, Copenhagen).

About 30 mussels, $3-5 \mathrm{~cm}$ in shell length, were collected in the littoral zone at low tide from the study site in Breidifjördur and from a suspended population in Mjoifjördur at $2 \mathrm{~m}$ depth. The population in Breidifjördur was continuously submerged except at lowest tide about 6 hours per month. The greatest difference between ebb and low tide in Breidifjördur is about $6 \mathrm{~m}$, but in Mjoifjördur it is only about $1 \mathrm{~m}$. The population structure density and size distribution were similar at both sites. The samples were collect- ed twice a month between March and November but monthly at other times of the year. The investigations were carried out from July 1995 to August 1997 in Breidifjördur and from January to November 2000 in Mjoifjördur.

In the laboratory small samples of the gonads were removed from the mussels and preserved in $10 \%$ formaldehyde. Later histological preparations were made by dehydration of the gonad samples through an ascending alcohol series, clearing in toluene and embedding in paraffin. Sections were cut about $7 \mu \mathrm{m}$ in thickness and stained with hematoxylin and eosin.

The stained gonad preparations from each mussel were classified into different developmental stages, under a microscope, using $80 \times$ magnification. The classification consisted of four main stages, two of which (developing and spawning) were further divided into four substages, resulting in a total of ten stages, developing (1 - 4), ripe (5), spawning (4 - 1) and spent (0) (Seed 1969). In stage 0 (spent) it is difficult to determine the sex of the animals but in some cases eggs were visible even though the spawning was over. In these cases the samples were classified as spent and the sex was given.

The reproductive condition of the population was assessed by calculating a mean gonad index. This was done by multiplying the number of mussels in each stage by the numerical ranking of that stage and dividing the resulting value by the total number of mussels in the sample. The mean gonad index for each sampling date was then calculated by adding together the scores for all stages (Seed 1969). If all individuals were spent, the gonad index would be 0 (minimum) and if all individuals were fully ripe the index would be 5 (maximum).

\section{Results}

\section{Temperature}

The maximum mean monthly sea temperature in Breidifjördur, western Iceland, was reached in July and August in $1995\left(10.1^{\circ} \mathrm{C}\right)$ and in August $1996\left(11.0^{\circ} \mathrm{C}\right)$. The minimum temperature was observed in February $1996\left(0.8^{\circ} \mathrm{C}\right)$ and in March $1997\left(-0.1^{\circ} \mathrm{C}\right.$; Fig. 2). The maximum mean monthly sea temperature in Mjoifjördur, eastern Iceland, was observed in August $\left(9.8^{\circ} \mathrm{C}\right)$ and the minimum $\left(1.3^{\circ} \mathrm{C}\right)$ in March.

Reproductive cycles of Mytilus edulis L., Iceland 
Fig. 2. Sea surface temperature at the sampling site in Breidifjördur, western Iceland, from July 1995 to May 1997 and in Mjoifjördur, eastern Iceland, from January to December 2000

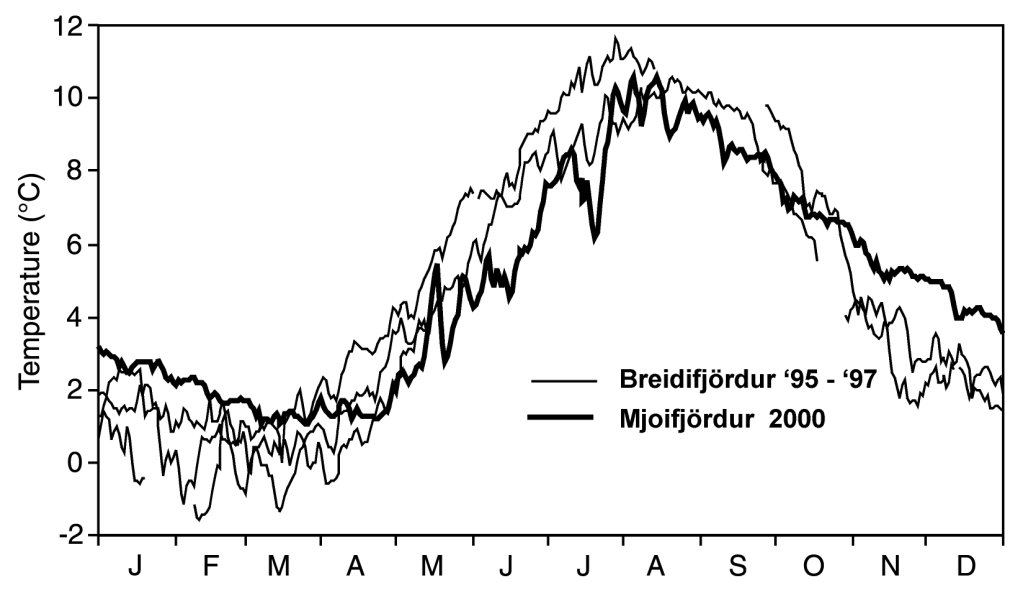

Fig. 3. Chlorophyll-a concentration at the sampling site in Breidifjördur, western Iceland, from July 1995 to March 1997 and in Mjoifjördur, eastern Iceland, from January to October 2000.

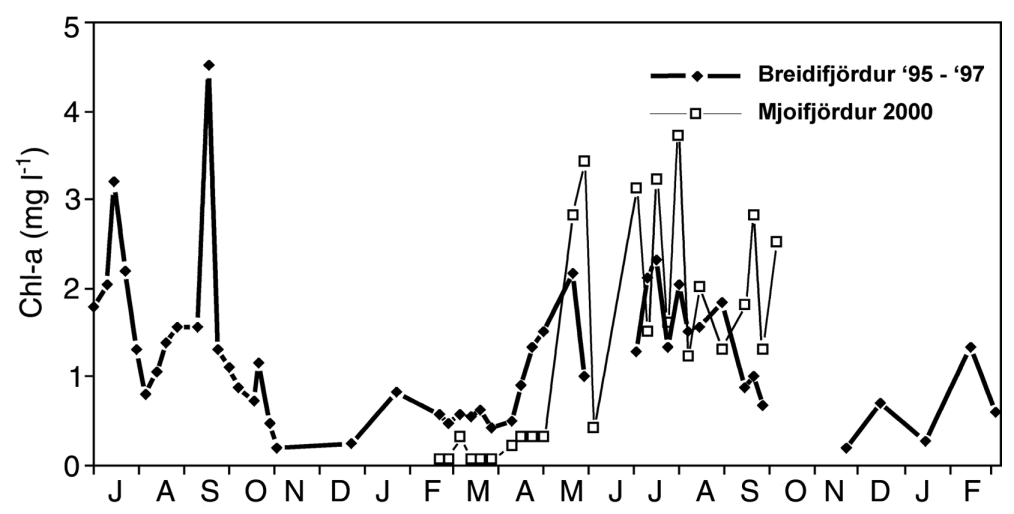

Salinity

In Breidifjördur small variations in salinity were observed. Salinity ranged from a minimum of 33.8 in September 1995 and March 1996 to a maximum of 34.9 in October 1996. In Mjoifjördur salinity varied much more than in Breidifjördur. The salinity varied between 32 and 34 from February until May, then fell abruptly to a minimum of 13.6 in the middle of May, increased rapidly again to a steady level of $32-33$ until July, when it decreased to $22-28$. The salinity increased to about 33 again in August and kept that level to the end of the year.

\section{Chlorophyll-a}

A maximum of the mean monthly values of Chl-a in Breidifjördur was reached in July and September $1995\left(2.1 \mu \mathrm{g} \mathrm{l}^{-1}\right)$ and in July $1996\left(1.8 \mu \mathrm{g} \mathrm{l}^{-1}\right)$. A minimum of $0.2 \mu \mathrm{g} \mathrm{l}^{-1}$ was observed in Decem- ber 1995 and in November 1996. The maximum values observed in 1995 were in July 15 $\left(3.2 \mu \mathrm{g} \mathrm{l}^{-1}\right)$ and September $16\left(4.5 \mu \mathrm{g} \mathrm{l}^{-1}\right)$. In 1996 the maximum value was observed on 17 July $(2.2$ $\left.\mu \mathrm{g} \mathrm{l}^{-1}\right)$. A minimum value was $0.2 \mu \mathrm{g} \mathrm{l}^{-1}$ on 23 December 1995 and 23 November 1996 (Fig. 3). In Mjoifjördur the Chl-a level was below detection limit in the samples from January through April. It started increasing in late May and the mean monthly values peaked in July at $2.7 \mu \mathrm{g} \mathrm{l}^{-1}$. A maximum value of $3.7 \mu \mathrm{g} \mathrm{l}^{-1}$ was observed in the end of July (Fig. 3).

\section{Gametogenic cycle}

In Breidifjördur, western Iceland, there appeared to be no difference in gametogenesis or spawning between males and females and the general patterns of gametogenesis and spawning were similar in both years investigated. The highest values of the mean gonad index, 4.2 and 4.8, were 


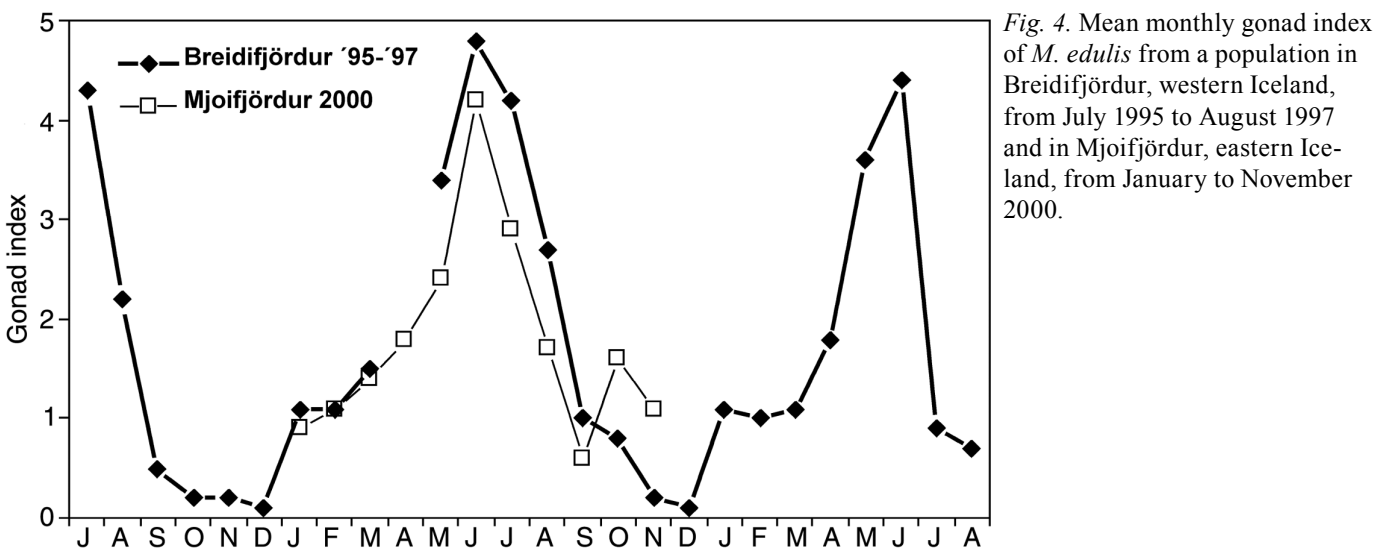

attained in July both years investigated (Fig. 4) coinciding with highest number of ripe individuals (Fig. 5). At the start of the sampling period in July 1995, 38\% of the population $>30 \mathrm{~mm}$ was spawning. The main spawning period was in August (100\%) but some spawning continued until November. In 1996 few individuals spawned in July (13\%) but the main spawning period was again in August (82\%), continuing through the autumn. In 1997 spawning started a month earlier than the year before or in June (10\%) but was most intensive in July and August (56\% each month). After the marked spawning period, both years investigated, the gonad index fell to a minimum (0.2) in November (Fig. 4) when most of the individuals were in the spent condition (Fig. 5). In January the gonad index slowly increased again (Fig. 4) with most of the individuals investigated in developing stages until May (Fig. 5).

In Mjoifjördur, eastern Iceland, the highest gonad index, 4.2, was attained in June (Fig. 4) coinciding with highest percentage of the population $(50 \%)$ in the ripe condition (Fig. 6). Spawning started in July and by the end of July, $87 \%$ of the individuals in the sample were spawning. In August over $90 \%$ of the individuals investigated were spawning. During the spawning period the gonad index decreased and in the middle of September its lowest value, 0.6, was observed (Fig. 4). At this time about $60 \%$ of the individuals were spawning but $40 \%$ were in the spent condition (Fig. 6). The development of gonads started immediately after spawning in the autumn and fully mature gametes were observed but now in small and few follicles. In October and November about $30 \%$ of the population was still spawning and all stages of gametogenesis were observed except ripe individuals (Fig. 6).

\section{Discussion}

The gametogenic cycle in the M. edulis population in Breidifjördur, western Iceland, was similar both years investigated. Development of gonads started in January, spawning started in July, it peaked in the beginning of August and extended until November. In Mjoifjördur, eastern Iceland, gametogenic cycle was different from the one in Breidifjördur as gametogenesis reinitiated in about half of the population in October and November while about one third of the population was still spawning. The follicles containing the gametes were, however, smaller and fewer than in the summer, indicating that gamete production and spawning was coming to an end. The development of the gametes in Mjoifjördur was slower in spring and the spawning started later in the summer than in Breidifjördur. Only a single period of spawning was observed at both sites. A similar gametogenic cycle with peak spawning in late summer has been observed in a suspended population in south-western Iceland (Thorarinsdóttir 1996).

The pattern of temperature changes differs in the two areas. With lower winter temperatures and higher summer temperatures, the amplitude is greater in Breidifjördur than in Mjoifjördur. This difference might cause faster development of the gonads in the spring in Breidifjördur than in Mjoifjördur although earlier phytoplankton blooming is also a possible causal factor. The development of gonads has been related to changes in temperature (Lubet 1959; Bayne 1975;

Reproductive cycles of Mytilus edulis L., Iceland 
Fig. 5. Percentage of M. edulis from Breidifjördur, western Iceland, in each phase of the gametogenic cycle from July 1995 to May 1997.

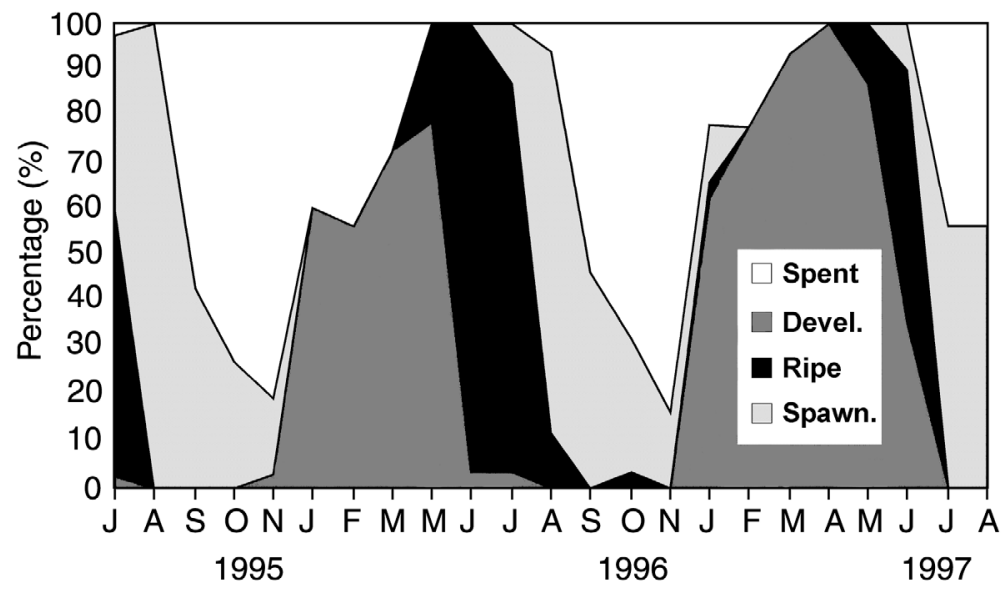

Fig. 6. Percentage of M. edulis from Mjoifjördur, eastern Iceland, in each phase of the gametogenic cycle from January to November 2000.

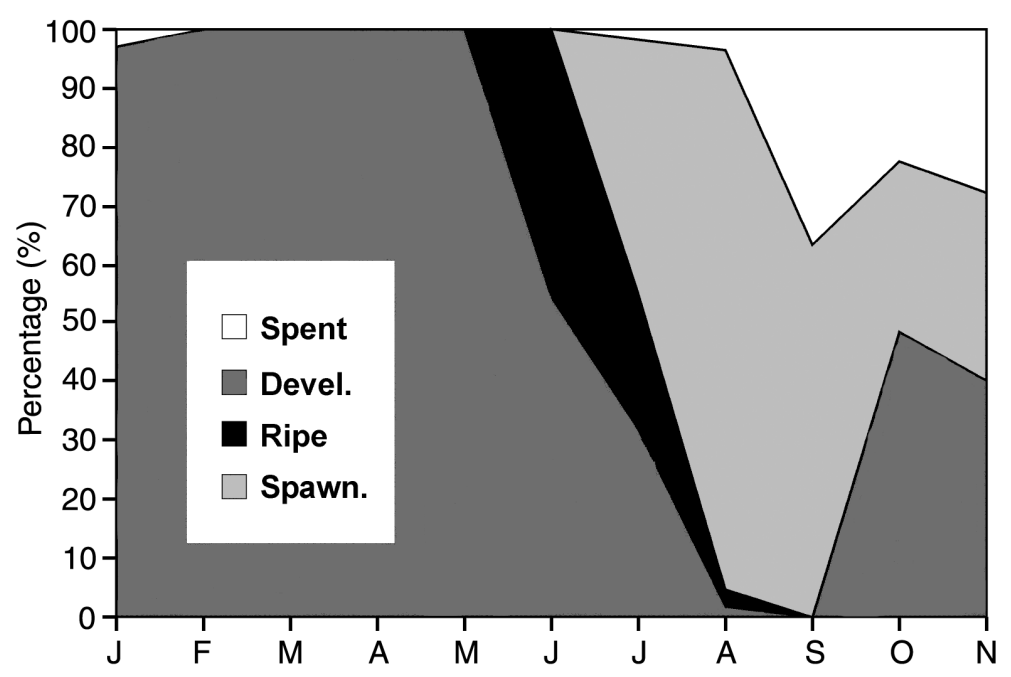

Gray et al. 1997) and temperature changes have also been shown to initiate spawning in already mature M. edulis (Chipperfield 1953; Sprung 1983). In fact some authors have suggested that critical temperature changes are needed for initiation of spawning in M. edulis (Seed 1976; Kautsky 1982), while others have found little or no evidence of this (Newell et al. 1982; Seed \& Suchanek 1992).

The salinity in Breidifjördur was relatively stable all the time investigated but in Mjoifjördur the salinity fluctuations are greater. The salinity decreased abruptly and intensively in May, for example. But this could not be connected to any events in the development of the gonads or spawning. Fell \& Balsamo (1985) equally failed to establish any such association in M. edulis, although salinity changes have been connected with the onset of spawning in the related mussel Perna viridis (Parulekar et al. 1982).

At both Breidifjördur and Mjoifjördur the development of the gonads in $M$. edulis took place during the middle of the winter when food supply, gauged by Chl-a values and sea temperature, were near their respective minima. Gametogenesis is therefore likely to have depended on accumulated reserves from the previous year. The increasing food supply and water temperature in April in Breidifjördur and a month later in Mjoifjördur seem to have accelerated the gonad development, leading to maturation in June in Breidifjördur and in the middle of July in Mjoifjördur at sea temperatures of about $8^{\circ} \mathrm{C}$.

The annual reproductive cycle of $M$. edulis has 
been related to the seasonal cycle in food supply (Thompson 1979; Newell et al. 1982). Spawning is thought to be timed such that both larvae and adults have access to abundant food supplies (Thompson 1979; Newell et al. 1982). Since food availability is likely to influence larval success in marine benthic invertebrates, the use of phytoplankton as a cue for spawning could be an adaptation to ensure abundance of food for the planktotrophic larvae that attain the feeding veliger stage within a few days after spawning. The food supply for the mussels at both sites was highest at the onset of spawning in July and was relatively high until October. The larvae have thus probably had abundant food supply during development and settlement.

There is a considerable variation in the timing and duration of gametogenesis and spawning in M. edulis (Lowe et al. 1982). In many European populations nutrient reserve, which have accumulated in the mantle tissue during the summer, functions as an energy source for gametogenesis during autumn and winter when food supply is limited (Gabbott 1983). Peak spawning is then observed in spring or early summer, sometimes extended with more than one spawning peak (Bayne 1976). This type of gametogenic cycle has been observed e.g. in western Norway (Barkati 1990), the Faroe Islands (Thorarinsdóttir et al. unpubl. ms.), Ireland (Snodden \& Roberts 1997), Wales (Lowe et al. 1982), Germany (Sprung 1983), Portugal (Reis-Henriques \& Coimbra 1990), the Baltic (Kautsky 1982) and the Wadden Sea (Pieters et al. 1979). In Long Island Sound, off the east coast of the United States, Brousseau (1983) also observed a population with a similar pattern of gametogenesis.

Another pattern of the gametogenic cycle in $M$. edulis occurs when carbohydrate stores are limited and used for initiation of gonad development in winter but are not sufficient for maturation of the gonads. The main growth of the gonads occurs in spring in conjunction with phytoplankton blooming and renewal of food resources and spawning occurs in late summer. This is the pattern found in the M. edulis populations in Iceland and has also has been observed in populations in Newfoundland (Thompson 1984), eastern Canada (Newell et al. 1982) and off the west coast of the United States (Emmet et al. 1987).

The results from the present study indicate that the gametogenic cycles in the two mussels populations investigated were not the same. In Mjoi- fjördur, gametogenesis was initiated in autumn but in January in Breidifjördur. The temperature and food supply in autumn at the two sites were not significantly different but the coming winter temperature in Mjoifjördur was higher than in Breidifjördur. The adaptation of the mussels to higher sea temperature in the winter might explain the onset of gametogenesis at this time of the year. In January, the gametogenesis speeded up in both populations in spite of low temperature and lack of food. Possibly due to later onset of phytoplankton production, the development of the gametes in the mussels in Mjöifjordur was slower in spring and the spawning started later in summer than in Breidifjördur.

As more information on Mytilus edulis is gathered, it becomes clear that the traditional view of a single fixed pattern of gametogenesis and spawning for a population is inadequate. Rather, some flexibility is shown with different adaptations to variations in environmental factors.

Acknowledgements.-We thank Halldóra Skarphéðinsdóttir for various help in planning and execution of the study. Sigfús Vilhjálmsson and Ingólfur Sigfússon collected samples of mussels and phytoplankton in Mjoifjördur and Hrönn Hafsteinsdóttir collected the samples in Breidifjördur-we are grateful to them. We also thank Elena Guijarro Garcia and Kristín Valsdóttir for assistance in the laboratory and Al Kutzchera for preparing thin sections of gonads. Thanks are also due to Jørgen Hylleberg for reading and improving the manuscript.

\section{References}

Barkati, S. 1990: Reproduction of the mussel Mytilus edulis L. from Lindåspollen, western Norway. Oebalia 19891990 16, 1-14.

Bayne, B. L. 1975: Reproduction in bivalve molluscs under environmental stress. In F. J. Vernberg (ed.): Physiological ecology of estuarine organisms. Pp. 259-277. Columbia, SC: University of South Carolina Press.

Bayne, B. L. 1976: Aspects of reproduction in bivalve molluscs. In M. Wiley (ed.): Estuarine processes. Vol. 1. Uses, stresses and adaptation to the estuary. Pp. 432-448. New York: Academic Press.

Brousseau, D. J. 1983: Aspects of reproduction of the blue mussel, Mytilus edulis (Pelecypoda: Mytilidae), in Long Island Sound. Fish. Bull. 81, 733-739.

Chipperfield, P. N. J. 1953: Observations on the breeding and settlement of Mytilus edulis (L.) in British waters. J. Mar. Biol. Assoc. U. K. 32, 449-476.

Emmett, B., Thompson, K. \& Popham, J. D. 1987: The reproductive and energy storage cycles of two populations of

Reproductive cycles of Mytilus edulis L., Iceland 
Mytilus edulis (Linne) from British Columbia. J. Shellfish Res. 6, 29-36.

Fell, P. E. \& Balsamo A. M. 1985: Recruitment of Mytilus edulis L. in the Thames Estuary, with evidence for differences in the time of maximal settling along the Connecticut shore. Estuaries 8, 68-75.

Gabbott, P. A. 1983: Development of seasonal metabolic activities in marine molluscs. In P. W. Hochachka (ed.): The Mollusca. Vol. 2. Environmental and biochemical physiology. Pp. 165-217. New York: Academic Press.

Giese, A. A. 1959: Comparative physiology: annual reproductive cycle of marine invertebrates. Ann. Rev. Physiol. $21,547-576$

Gray, A. P., Seed, R. \& Richardson, C. A. 1997: Reproduction and growth of Mytilus edulis chilensis from the Falkland Islands. Sci. Mar. 61,39-48.

Jeffrey, S. W. \& Humphrey, G. F. 1975: New spectrophotometric equations for determining chlorophylls $\mathrm{a}, \mathrm{b}, \mathrm{c}_{1}$ and $\mathrm{c}_{2}$ in higher plants, algae and natural phytoplankton. Biochem. Physiol. Pflanz. 167, 191-194.

Kautsky, N. 1982: Quantitative studies on gonad cycle, fecundity, reproductive output and recruitment in a Baltic Mytilus edulis population. Mar. Biol. 68, 143-160.

Lowe, D. M., Moore, M. M. \& Bayne, B. L. 1982: Aspects of gametogenesis in the marine mussel Mytilus edulis L. J. Mar. Biol. Assoc. U. K. 62, 133-145.

Lubet, P. 1959: Recherches sur le cycle sexuel et l'émission des gamètes chez les Mytilides et les Pectinides. Rev. Trav. Inst. Pêches Marit. 23, 395-548.

Newell, R. I. E., Hilbish, T. J., Koehn, R. K. \& Newell, C. J. 1982: Temporal variation in the reproductive cycle of Mytilus edulis L. from localities on the east coast of the United States. Biol. Bull. 162, 299-310.

Parulekar, A. H., Dalal, S. G., Ansari, Z. A. \& Harkantra, S. N. 1982: Environmental physiology of raft-grown mussels in Goa, India. Aquaculture 29, 83-93.

Pieters, H., Kluytmans, J. H., Zurberg, W. \& Zandee, D. I. 1979: The influence of seasonal changes on energy metabolism in Mytilus edulis (L). I. Growth rate and biochemica composition in relation to environmental parameters and spawning. In E. Naylor \& R. H. Hartnoll (eds.): Cyclic phenomena in marine plants and animals. Pp. 285-293. New York: Pergamon Press.
Reis-Henriques, M. A. \& Coimbra, J. 1990: Variations in the levels of progesterone in Mytilus edulis during the annual reproductive cycle. Comp. Biochem. Physiol. 95A, 343348.

Seed, R. 1969: The ecology of Mytilus edulis L. on exposed rocky shores. I. Breeding and settlement. Oecologia (Berlin) 3, 277-316.

Seed, R. 1976: Ecology. In B. L. Bayne (ed.): Marine mussels: their ecology and physiology. Pp. 13-65. Cambridge: Cambridge University Press.

Seed, R. \& Brown, R. A. 1977: A comparison of the reproductive cycles of Modiolus modiolus (L.) Cerastoderma (=Cardium) edule (L) and Mytilus edulis (L) in Strangford Lough, Northern Ireland. Oecologia (Berlin) 30, 173-188.

Seed, R. \& Suchanek, T. H. 1992: Population and community ecology of Mytilus. In E. Gosling (ed.): The mussel Mytilus: ecology, physiology, genetics and culture. Pp. 87196. London: Elsevier.

Snodden, L. M. \& Roberts, D. 1997: Reproductive patterns and tidal effects on spat settlement of Mytilus edulis populations in Dundrum Bay, Northern Ireland. J. Mar. Biol. Assoc. U. K. 77, 229-243.

Sprung, M. 1983: Reproduction and fecundity of the mussel Mytilus edulis at Helgoland (North Sea). Helgol. Meeresunters. 36, 243-255.

Starr, M., Himmelman, J. H. \& Therriault, J. 1990: Direct coupling of marine invertebrate spawning to phytoplankton blooms. Science 247, 1071-1074.

Thompson, R. J. 1979: Fecundity and reproductive effort in the blue mussel (Mytilus edulis), the sea urchin (Strongylocentrotus droebachiensis) and the snow crab (Chionoecotes opilio) from populations in Nova Scotia and Newfoundland. J. Fish. Res. Board Can. 36, 955-964.

Thompson, R. J. 1984: The reproductive cycle and physiological ecology of the mussel Mytilus edulis in a subarctic, nonestuarine environment. Mar. Biol. 79, 277-288.

Thorarinsdóttir, G. G. 1996: Gonad development, larval settlement and growth of Mytilus edulis L. in a suspended population in Hvalfjördur, south-west Iceland. Aquac. Res. 27, 57-65.

Thorarinsdóttir, G. G., Gunnarsson, K. \& Dam, M. unpubl. ms.: Gonad development in Mytilus edulis L. in the Faroes 